\title{
ROLAND BARTHES OU AS VISÕES DE HILDEGARDA
}

\author{
Affonso Romano de Sant'Anna \\ UFRJ \\ "É preciso que o discurso se faça. Então, \\ inventam-se as obscuridades"
}

Beckett

\begin{abstract}
RESUMO
O trabalho reflete sobre os limites da interpretação, tendo como eixo a leitura, por Barthes, de três desenhos de Cy Twombly.
\end{abstract}

PALAVRAS-CHAVE

Barthes. Twombly. Estética. Interpretação

\section{Par où COMmencer?}

$U_{m}$ antigo ensaio de Barthes com o título - "Por onde começar?", me ocorre agora que me disponho a estudar os textos nos quais ele discorre sobre a obra do pintor norte-americano Cy Twombly. ${ }^{1}$ Como ele, fico em dúvida por onde começar, tantos e concomitantes são os ângulos solicitando meu enfoque.

Poderia começar simplesmente reproduzindo três quadros daquele pintor referidos e mostrados por Barthes e aguardar que o leitor reflita sobre o significado que possam ter ou que conclua que tipo de sensação esses quadros lhe comunicam. Seria, evidentemente, um processo recomendável e produtivo, pois poria o leitor diante de uma obra sem o condicionamento que a explicação crítica adiciona posteriormente à visão. Estou pressupondo, com alguma razão, que o leitor deste ensaio não é um leitor ingênuo ou despreparado. Ao contrário, se está com esta revista aberta em suas mãos é porque lhe interessam as questões aqui levantadas sobre a arte no nosso tempo.

Então, proponho, como primeira possibilidade de enfoque, vejamos simplesmente essas reproduções:

\footnotetext{
${ }^{1}$ BARTHES. O óbvio e o obtuso.
} 


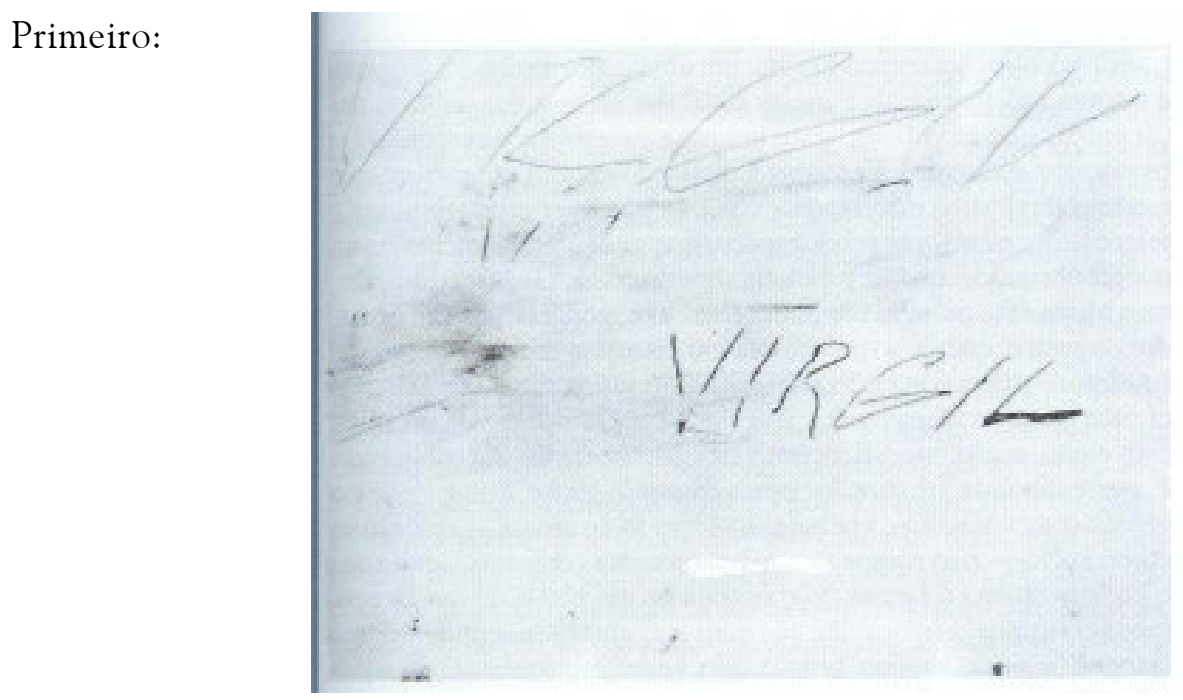

Segundo:

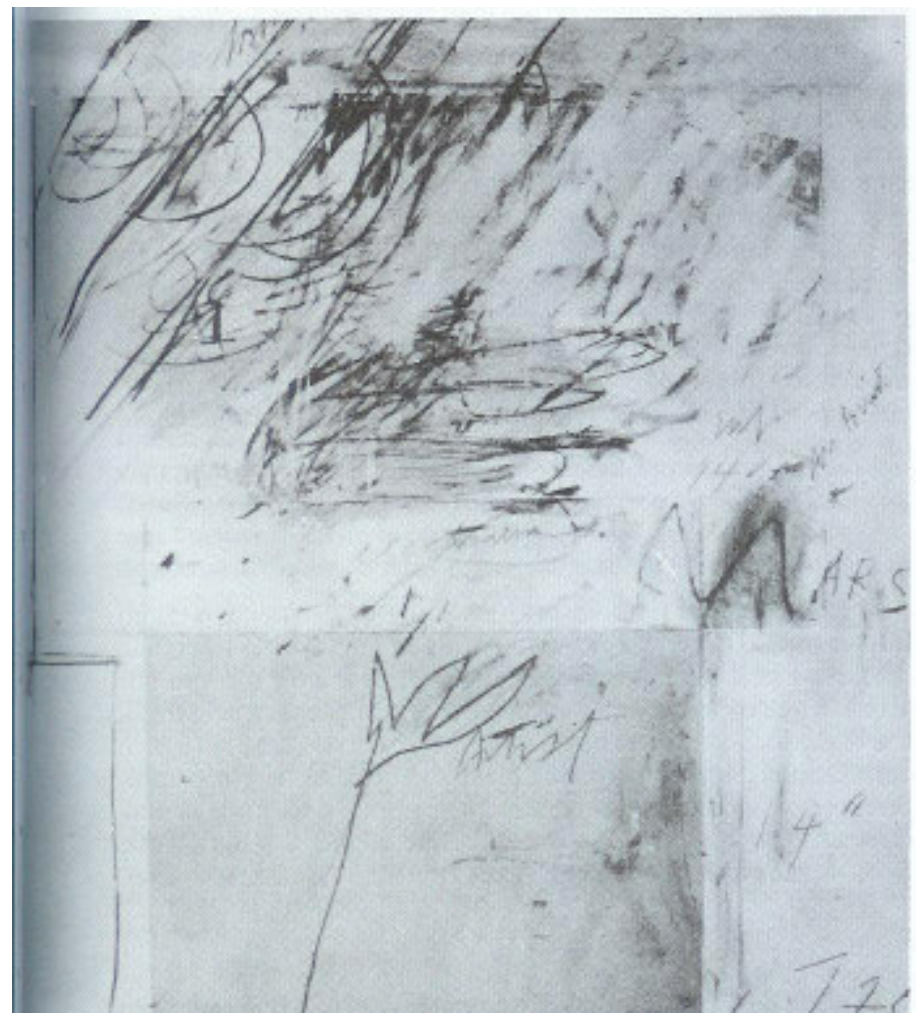

Terceiro:
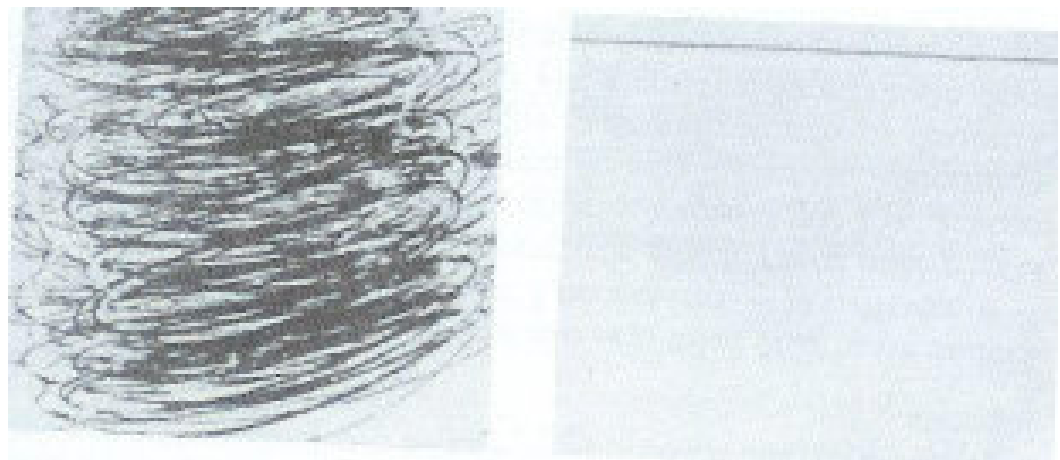

158 AletriA - v. 18 - jul.-dez. - 2008 
Seria interessante que o leitor, uma vez tendo visto essas reproduções, anotasse numa folha de papel o que lhe ocorreu sobre essas obras; ou seja, tudo o que lhe passou pela cabeça, e só depois, prosseguisse na leitura deste ensaio. Ou, que o leitor guarde suas anotações e depois as confira mostrando as convergências e divergências em relação a Barthes ou a este ensaísta.

A segunda possibilidade de começar seria mostrar aqueles trabalhos e indicar logo minha discordância e espanto. E, só depois, iniciar a análise de algumas afirmativas e estratégias do semiólogo francês. Neste sentido esclareço que já havia visto obras de Cy Twombly, primeiramente no Beaubourg e depois em outros museus. Portanto, minhas observações não partem de reproduções e sim do não-impacto dos originais. Assim é que não vi nada de transcendental, por exemplo, nesses grafitos e na série de rabiscos circulares, como o terceiro quadro reproduzido aqui.

A sensação era diametralmente oposta à de Barthes. Ele diz "considero os 'grafismos' de TW pequenos satoris". Quer dizer, como no pensamento oriental, uma verdadeira revelação, uma epifania. E diante do que ele reconhece serem "rabisco", "mancha" e "negligência", o arrebatamento é de tal ordem, que Barthes diz que aí "há uma forma de traçado que poderíamos chamar de sublime". E isto posto, confessa chegar ao "gozo" ("assim podemos dizer 'gozar' o movimento que resulta do gesto"). E depois de afirmar que essa obra é "inimitável" e que ela chega a "explodir o Museu" (assim mesmo Museu com M maiúsculo), como se fosse mais radical do que tudo o que de radical já se fez, antes e depois de Duchamp, ele parte para analogias, colocando o autor definitivamente no olimpo da arte e do pensamento não só ocidental, mas oriental.

Recorre, então, à filosofia zen, ao taoismo, à tradição milenar da caligrafia, chega a compará-lo a Paul Klee, vai buscar a técnica de composição em Webern, em Alban Berg e nos hai-kais japoneses, cita Nietzsche, lança a teoria do jogo em Winnicot, invoca Mallarmé, Bachelard, Valéry, Keats, Poussin, Sade, Rafael, Ovídio, tudo para concluir que a grande "singularidade" deste pintor é que "não quer captar nada", posto que na sua obra não há "nada a decifrar" e que aí "não vemos nada, salvo uma espécie de inteligibilidade".

Estamos diante de uma situação exuberantemente paradoxal que talvez possa ser definida também como um exercício retórico sobre a superabundância do nada.

Leio as análises de Barthes e começo a me colocar em xeque. Como explicar tamanha diferença de percepção e de avaliação entre duas pessoas em relação a uma obra? Sobretudo levando-se em conta a admiração que tenho pelo ensaísta francês, a citação que já fiz de obras suas. Em mais de 30 anos de vida acadêmica me servi, positivamente, de vários textos de Barthes e no livro O óbvio e o obtuso, esse mesmo que traz os ensaios sobre $\mathrm{Cy}$, há outros textos notáveis, com os quais estou afinado, como o estudo que faz de Arcimboldo e o outro sobre as letras em formato de corpo feminino desenhadas por Erté. Curiosamente, havia, com Marina Colasanti, traduzido para o português, nos anos 70, o belo livro de Barthes sobre Erté, ${ }^{2}$ obra pertencente à estupenda coleção de Franco Maria Ricci. Indispensável dizer, portanto, que o considero um mestre. Enfim, de Barthes sei de sua obra, estive metido em questões de linguagem a vida inteira, participando e escrevendo sobre arte e literatura.

\footnotetext{
${ }^{2}$ BARTHES. Erté.
} 
Procurei, por outro lado, rever a obra de Cy Twombly. Conhecer melhor sua trajetória. Quem sabe eu estava equivocado na minha primeira impressão quando vi seus quadros em museus estrangeiros? Fui então conhecer melhor sua biografia, lendo ensaios sobre ele e sua geração, vendo os volumes sofisticados e caros que reproduzem (com elogios de notáveis) a sua obra. ${ }^{3}$ Interessei-me até por livros como "Significant others", ${ }^{4}$ no qual se estuda a "criatividade e as parcerias íntimas", como foi a convivência erótica \& artística entre Cy Twombly e Rauschemberg, antes que Jasper Jones arrebatasse o segundo do primeiro. E minha primeira impressão sobre sua obra continuou a mesma. A sensação que se tem, terminada a leitura dos ensaios de Barthes, é que o quadro permanece praticamente intacto. Continua raso. Profundo é o ensaio. E este é o ponto a ser analisado, como o faremos mais adiante.

Então, sobre Cy Twombly, me pergunto: sei de que geração vem; sei dos marchands americanos astuciosos que o cercaram e como as leis de mercado promulgam valores; sei das teorias sobre grafites e sua importância sócio-estética; conheço as teorias sobre arte; sei do contexto ideológico da "guerra fria" em que a obra de Cy foi divulgada; sei algo de sua biografia. E, no entanto, nenhum "satoris", nenhuma revelação "sublime" me envolveu num gozo epifânico.

Alguém pode alegar que a falha é minha. Que falta aderência em mim. E se isto for verdade, esse ensaio bem pode terminar nesta parte. Quem assim simplificar a questão pode parar por aqui e se dar por satisfeito, evitando o esforço de ter que raciocinar e entrar em certas questões epistemológicas que têm a ver com a cegueira e o saber.

Mas suponhamos que ao leitor-admirador de Barthes interesse continuar tentando entender por outras vias esta intrincada questão, que é menos pessoal que estética e filosófica. Que esteja interessado não em ser contra ou a favor de A ou B (de Affonso ou Barthes), mas interessado em vislumbrar algum caminho dentro de tantos quiproquós teóricos da modernidade, Neste caso, talvez valha a pena continuar a leitura. Talvez valha tentar explicitar de onde nascem as diferenças de leitura e de percepção que podem chegar a uma vasta divergência.

\section{Partindo para a anÁlise}

Considerando que este ensaio tem como objetivo estudar a interpretação que Barthes faz de Cy Twombly, é natural e imprescindível dar a palavra ao ensaísta e ler como ele abre seu estudo. Leiamos:

Quem é Cy Twombly (que, aqui, chamaremos TW)? O que faz? Como dar um nome ao que faz? Palavras surgem espontaneamente ("desenho", "grafismo", "rabiscos", gauche, "infantil”). E, aqui nos encontramos diante de um problema de linguagem: essas palavras (o que é bastante estranho), não soam falso nem bem; pois, por um lado a obra de TW coincide plenamente com sua aparência, e é necessário atrever-se a afirmar que é uma obra banal; mas, por outro lado, - e aqui reside o enigma -, esta aparência não coincide

\footnotetext{
${ }^{3}$ LEEMAN. Cy Twombly; DelRoscio. Writing on Cy Twombly.

${ }^{4}$ Ver CHADWICK; COURTIVRON (Ed.). Significant Others.
} 
com essa linguagem, que deveria despertar sentimentos de simplicidade e inocência naqueles que a contemplam. "Infantis" os grafismos de TW? Sim, e por que não? Mas, não apenas infantis: há algo de mais, ou de menos, ou algo paralelo. Dizem: esta tela de TW é isto, é aquilo; mas trata-se antes de algo de muito diferente, a partir disto ou daquilo: em uma palavra, ambígua porque literal e metafórica, é deplacée." ${ }^{5}$

No parágrafo seguinte, Barthes acrescenta mais uns toques fundamentais na sua interpretação:

Percorrer a obra de TW com os olhos e com os lábios é, pois, um permanente negar aquilo que parece ser. É uma obra que não exige que se contradigam as palavras da cultura (a espontaneidade do homem é sua cultura), simplesmente que se as desloque, que se as destaque, que se lhes dê outro enfoque. TW força, não a recusar, mas - o que é, talvez, mais subversivo - a traspassar o estereótipo estético; enfim, obriga-nos a um trabalho de linguagem (e não é exatamente esse trabalho - nosso trabalho - que dá seu valor a uma obra?). ${ }^{6}$

Convenhamos que este é um texto sofisticado, e até rebuscado. Não pode ser lido de um fôlego só. Há cinco parêntesis fazendo com que o leitor interrompa ou desentranhe algo subentendido na leitura. Há também, como num palimpsesto (em que vários textos estão atrás de outros textos), palavras entre aspas e em grifo, denotando significados e sutilezas. É um texto com vários sub-textos e pré-textos. E, do ponto de vista do conteúdo propriamente dito, o autor está propondo um tipo de leitura não só original, mas subjetiva da obra de Cy Twombly.

Poder-se-ia dizer que o tipo de leitura produzido por Barthes se assemelha aos desenhos do holandês Maurits Escher (1898-1972). Tais desenhos são a representação de labirintos que sobem e descem, que parecem levar a um lugar sem saída e encontram na não-saída, a saída, como se portas e janelas fossem se abrindo no desenho do próprio texto. É o que eu chamaria de escrita "à la Escher". Uma escrita "en abîme", que cai e desliza sobre si mesma continuamente. Um ourobouro, serpente que devora a própria cauda. Ilusionista, também. Descentrada, elíptica, que provoca vertigem e aprisiona. Tem, como outros textos de Barthes, algo encantatório e sedutor. É um jogo de espelhos, de verossimilhanças que se remetem a si mesmas num plano supra real. Em síntese, o escritor está falando com a sua própria escrita, a obra do artista é pré-texto.

Aproximando-nos, porém, um pouco mais da estrutura do texto, podemos configurar mais claramente que estratégia retórica e discursiva Barthes colocou em marcha.

1. Está zerando o conhecimento seu e do leitor, atraindo-o para um espaço inaugural, que ele domina, onde o ensaísta é soberano. Ao mesmo tempo, inaugurando esse espaço desconhecido, tenta desentranhar questões básicas sobre "quem é?", "o que faz?", e que "nome" dar à estranha obra daquele artista.

2. Ele assinala, também, um paradoxo, algo que poderia ser tido como um oxímoro central, pois nessa obra aparentemente "banal", com simples desenhos-grafismorabiscos, "há algo mais, ou de menos, ou algo paralelo" que tem que ser visto e ou descrito, posto que essa obra nega "aquilo que parece ser".

\footnotetext{
${ }^{5}$ BARTHES. O óbvio e o obtuso, p. 143.

${ }^{6}$ BARTHES. O óbvio e o obtuso, p. 143.
} 
3. Portanto, para que se conheça autenticamente o sentido dessa obra, só mesmo um "trabalho de linguagem", ou seja, algo que, como diz, se insere no espaço do "nosso" trabalho.

E exatamente porque é "nosso" esse "trabalho de linguagem" e porque estou também inserido na comunidade dos que trabalham a linguagem e com a linguagem, é que considero irrecusável o convite para ler criticamente o texto do escritor Barthes e a obra de Cy Twombly, que se utiliza da linguagem verbal dentro da pintura. Não é, portanto, à toa que Barthes vai dizer que aqui temos que operar uma leitura com os "olhos" mas também com os "lábios". Está, de alguma forma, se referindo ao discurso, à palavra, que saindo da boca do criador, dá sentido às coisas.

Dois problemas surgem de imediato e entrelaçadamente. Primeiro Barthes coloca a obra de Cy Twombly no espaço do "enigma". Ele diz: "aqui reside o enigma". Com efeito, é próprio do enigma ser paralisante. Ele interrompe os passos daquele que quer penetrar no espaço do sagrado e do mistério. Está fixado na porta das cidades antigas e na porta do texto de Barthes. E como enigma não é transparente. Não se deixa decodificar ao primeiro olhar. O leitor é logo colocado, como nos rituais místicos e tribais, no limiar de uma iniciação e de alguma maneira entrega ao ensaísta o papel de conduzi-lo nessa "selva oscura".

Essa é a trilha que Barthes segue e vai alargando. Envolvendo a obra do pintor na atmosfera do enigma, passa noutro ensaio sobre Twombly, justamente intitulado "A sabedoria da arte" a elaborar a ambígua questão do sentido do não-sentido. ${ }^{7} \mathrm{O}$ ensaísta está nos dizendo que diante de uma obra que parece banal, mas é profunda, o não sentido dela é que é o seu sentido. E para que aceitemos o sentido do não-sentido ele então nos coloca em guarda contra o desejo de querer ver sentido nas coisas e discursos, como se estivesse a nos dizer que a melhor maneira de ver é fechar os olhos:

O sentido engana o homem: mesmo quando quer criar o não-sentido ou o sem-sentido, o homem acaba por produzir o próprio sentido do não-sentido ou do sem-sentido. É assim procedente voltar sempre ao problema do sentido, único problema que constitui um obstáculo à universalização da pintura. Se tantos homens (devido às diferenças de cultura) têm a impressão de "nada entender" diante de uma tela, é porque nela procuram um sentido, e a tela (pensam eles) não lhes oferece nenhum. ${ }^{8}$

Estamos num círculo vicioso e/ou num beco sem saída. Estamos numa selva escura e nosso guia está nos pedindo que apaguemos a única vela que temos na mão, para, no escuro, caminharmos melhor. Enlaçados no não-sentido, estamos prisioneiros do sentido do não-sentido que o analista promete nos doar. Atônitos olhamos de novo os quadros e relemos o texto de Barthes. Há um vazio entre uma coisa e outra. E a correspondência entre eles, sobre ser voluntarista, é essencialmente retórica e literária. E mais grave, o autor reconhece que está inventando os quadros diante de si. É ele mesmo quem o diz:

\footnotetext{
${ }^{7}$ Essa complexa questão é abordada também por Gilles Deleuze, que, por sinal, tem uma obra intitulada A lógica do sentido. Para se ter uma visão crítica dessa filosofia, ver o que diz HOTTOIS em História da filosofia: da renascença à pós-modernidade.

${ }^{8}$ HOTTOIS. História da filosofia: da renascença à pós-modernidade, p. 166.
} 
"o quadro, qualquer um o pode escrever, só existe na narrativa que o 'escritor' lhe dá; ou ainda: na soma e na organização das leituras que dela se podem fazer: um quadro nunca é mais do que a sua própria descrição plural. Deste modo, é consequente o que ele vai dizer, no mesmo livro, no texto". ${ }^{9}$

Se a afirmativa é, de certa forma, verdadeira, pois um quadro é o resultado de suas múltiplas leituras, inclusive as contraditórias, é, por outro lado, fundamental destacar que nem todas as leituras se equivalem. Todas são possíveis, mas nem todas têm a mesma legitimidade. E a teoria de Barthes, resvala para um "relativismo" perigoso que caracteriza o pensamento pós-moderno. Como assinala Raymond Boudon:

Admitamos no entanto que o relativismo desempenha o mesmo papel que ocuparam o darwinismo social, o marxismo ou o positivismo noutros tempos. Diferentemente desses grandes movimentos de idéias, o relativismo é destituído de conteúdo. Ele nos diz apenas que toda interpretação do mundo é boa para ser desconstruída. ${ }^{10}$

O fato é que esse viés barthesiano de dar primazia à "escritura", de deslocar a análise para dentro de seu próprio texto reinventando alucinada e sedutoramente a obra alheia, leva-o a dizer arriscadamente que a "a própria prática do quadro é a própria teoria do quadro". Aí, surge claramente o escritor convertido em "gramatógrafo que escreve a escritura do quadro". Ele estava propondo algo fascinante enquanto literatura e arriscado enquanto crítica, quando, no mesmo livro que estamos citando, diz que está mesmo tentando inventar outra coisa:

Assistimos ao nascimento de alguma coisa, algo que anulará não só a "literatura", como também a "pintura" (e seus correlatos metalinguísticos, a crítica e estética), substituindo essas velhas divindades culturais por uma "ergografia" generalizada, o texto como trabalho, o trabalho como texto. ${ }^{11}$

Entende-se o fascínio que uma frase como essa exerceu há cerca de quarenta anos, no clima dos anos 60, em que um novo "discurso" surgiu na área das ciências humanas e sociais. Mas passou já o tempo de permanecermos tantalizados pela sedução da palavra que, pretendendo ser crítica, está pendendo mais para a ficção.

Estou me referindo ao que, no ensaio "Na sapataria de Jacques Derrida", chamei de uma espécie de "action writing", a escrita automaticamente gerando e proliferando sentidos, às vezes alucinadamente. Ou, então, para tomar um exemplo que Barthes deu no curso/livro sobre o "Neutro", a consciência e o discurso funcionam como alucinógenos, como drogas. A linguagem arrebata, cria significados. Não foi apenas Freud que viu alucinadamente um "abutre" no manto da Virgem, naquele quadro de Da Vinci. Outros grandes ensaístas e filósofos andam vendo "abutres" aqui e ali e experimentando o "satoris" às vezes diante do "minimalismo" e de monocromos. Não estranha que, distanciando-se da obra analisada, ou sobrepondo nela conteúdos outros, o "enigma" e o mistério vão ganhando densidade e inflando de sentido o não-sentido. Assim, ocorre o que o próprio

\footnotetext{
${ }^{9}$ HOTTOIS. História da filosofia: da renascença à pós-modernidade, p. 136.

${ }^{10}$ BOUDON. Misère du relativisme.

${ }^{11}$ BARTHES. O óbvio e o obtuso, p. 137.
} 
Barthes vai assinalar, quando, analisando a "semiografia de André Masson", diz: "para que a escritura seja manifestada em sua verdade (e não em sua instrumentalidade) é necessário que seja ilegível". ${ }^{12}$ Assim, o crítico se elege tradutor da ilegibilidade alheia. Como diz Beckett, dentro desse paradoxo, para que o discurso se faça, inventa-se a obscuridade.

\section{De VIRGIL A VIRGIL}

Mas retornemos às palavras de Barthes, para acompanhá-lo mais de perto em seus deslizamentos conceituais. É importante que o leitor volte ao quadro "Virgil" já mostrado. Que o olhe com atenção e agora confira com o que Barthes dirá sobre ele:

Quando TW escreve e repete uma única palavra - "Virgil", isso "já" constitui um comentário sobre Virgílio, pois o nome, escrito a mão, nos traz toda uma idéia da cultura antiga, e atua como uma citação: de um tempo antigo, de estudos desusados, calmos, preguiçosos, discretamente decadentes: colegas ingleses, versos latinos, carteiras, escritos a lápis. Assim é a cultura para TW: um bem-estar, uma lembrança, uma ironia, uma postura, um gesto "dandy".

Não fica muito claro se Barthes está falando de seu passado escolar, do passado de Cy ou da obra propriamente dita. E referindo-se a esse quadro o ensaísta segue dizendo: "Ao escrever Virgil sobre a tela, é como se Twombly resumisse em sua mão toda a enormidade desse mundo virgiliano, tudo o que esse nome simboliza". ${ }^{13}$

Será que isto realmente ocorre? Então, voltamos àquela falácia repetida e passível de ser desmontada teoricamente, que afirma (redutoramente) que o espectador é que faz, ou melhor, inventa a obra de arte, como se não houvesse algo mais complexo que passa por uma série de outras variáveis, como o autor e a própria obra. Fora isto, será que aquela grafia preguiçosa e intencionalmente mal feita, como reconhece o próprio Barthes, contém a "enormidade desse mundo virgiliano"? O ensaísta que é tão cuidadoso no uso das palavras teria se deixado trair pelo arrebatamento da escrita ou acredita mesmo neste absurdo?

Tirante o patente exagero dessa hiperinterpretação da simples palavra "Virgil", observa-se que, diante de uma escrita desleixada e quase apagada, o crítico não se detém sobre a materialidade do quadro. Está interessado na materialidade de sua escrita, no seu aspecto literário. Antes havia lembrado da "caligrafia", mas estranhamente não como arte, ou seja, da maneira como é cultuada no Oriente. Interessa-lhe uma anticaligrafia, "um rabisco, quase uma mancha, uma negligência". Assim as "escrituras" de TW "são restos de uma preguiça, consequentemente, de extrema elegância; como se, da escritura, ato erótico desgastante, restasse o cansaço amoroso: essa roupa caída, atirada a um canto da folha".

É, com efeito, um esforço gigantesco para valorizar o "banal". Uma transferência de libido extraordinária, à moda barthesiana, para impregnar de sensualidade a inóspita pintura de Cy Twombly. A rigor poder-se-ia colocar aqui um texto de Barthes, contra Barthes, que noutro trecho, referindo-se à arte conceitual, reconhece que ela, não tendo "nenhum lugar para o deleite", acaba matando o "desejo". Contra ele então se volta o seu próprio texto:

${ }^{12}$ BARTHES. O óbvio e o obtuso, p. 141.

${ }^{13}$ BARTHES. O óbvio e o obtuso, p. 147. 
A arte assume, então, sua própria teoria; não lhe resta mais nada senão falar consigo mesma, reduzindo-se ao discurso que "poderia" fazer sobre si mesma, se esse discurso consentisse em existir. Expulso o desejo, o discurso volta mais tarde: a arte torna-se "tagarela", no exato momento em que deixa de ser erótica. A ideologia e seu pecado foram afastados, é verdade; mas, o preço que se pagou é a 'aphanasis', a perda do desejo, em uma palavra, a castração. ${ }^{14}$

A essa antipintura (neutra? castrada?), sem desejo que é a de Cy Twombly, é que Barthes tenta conferir o que ela não tem, sem se dar conta de que aquele que denunciou o aspecto "tagarela" da critica está tagarelando sobre o "banal", tentando torná-lo profundo.

É, em suma, um exercício retórico formidável para elevar rabisco-manchanegligência à categoria de arte e ver nisto, não se sabe como nem por quê, uma "extrema elegância". De resto, as frases que se seguem são alucinação interpretativa de Barthes, ele falando dele mesmo, a exemplo da escritura como "ato erótico", e literariamente desenvolvendo metáforas sobre a roupa caída ou uma folha atirada num canto.

Como pode acontecer quando o escritor afoitamente assume o lugar do crítico, vão borbulhando devaneios pelo texto de Barthes. É bonito, até elegante, como ele o sabia ser, mas é pura literatura no sentido pejorativo. Estaria a literatura fagocitando as artes plásticas?

Teria sido eu o único a notar isto? Sou eu que estou alucinando solitariamente diante de uma tão grande autoridade? Não, felizmente. Sem procurar por uma exaustiva bibliografia, passo os olhos por minha estante e salta à minha mão o livro de Todorov, "Critique de la critique". ${ }^{15} \mathrm{E}$ descubro que não estou só, nem elocubrando temerariamente nisto que redijo. Todorov se dedica a estudar objetivamente os 'críticos escritores' e não os 'escritores críticos'. Exatamente aqueles que como Barthes, Sartre e Blanchot (é a seleção que ele faz) correm o risco de instalados de um lado do exercício da escrita viverem no sonho ou no exílio do que está noutra parte. O que ocorre com Barthes, eu diria, ocorre também com alguns outros pensadores e críticos. Sem precisar citar o clássico exemplo de Nietzsche - potencialmente um poeta e dramaturgo - adianto e confesso que lendo às vezes a obra de Jacques Derrida tenho a sensação de que ele queria ser romancista, que está distribuindo visuamente a massa de seu texto na página, como os ficcionistas de vanguarda, que, a rigor, estava prestes a começar seu "Ulisses", seu "Finnegans wake", que trespassou uma imponderável fronteira e pervaga siderado entre palavras tidas como coisas, monumentos, personagens e não mais como portadoras de um significado que o discurso crítico objetivamente encadeassse. Por sua vez, Gilles Deleuze incide na mesma direção e apresenta seu livro sobre a "lógica do sentido" como "uma tentativa de romance lógico e psicanalítico". ${ }^{16}$ Desponta, portanto, uma vez mais um tema que estava também nas metanálises que fizemos de Octávio Paz e Jean Clair. Estaria a filosofia sendo fagocitada pela literatura, ou vice-versa?

O caso de Barthes é mais patente, pois ele vem dizer claramente: "de minha parte não me considero como crítico, mas sim como um romancista, escriptor não de romance,

\footnotetext{
${ }^{14}$ BARTHES. O óbvio e o obtuso, p. 212.

${ }^{15}$ TODOROV. Critique de la critique. Un roman d'apprentissage.

${ }^{16}$ HOTTOIS. História da filosofia: da renascença à pós-modernidade, p. 418.
} 
é verdade, mas do "romanesco". ${ }^{17}$ E sabe-se que no fim da vida ele planejava algo como um romance "verdadeiro". Daí endossar que o ensaio seja "quase" romance, ou seja, é um "romance sem nomes próprios".

A rigor, e a seu favor, ele se equivoca. Os nomes próprios estão lá no ensaio romanceado. Podem aparecer como esse personagem que ele inventou, esse Cy Twombly que é o homônimo do pintor americano, mas totalmente imaginário e literário. E os nomes próprios dos personagens do crítico enquanto romancista estão nas bibliografias e citações diretas e indiretas. Os ensaístas e críticos, enquanto romancistas involuntários e inconscientes, têm a cabeça povoada de personagens como Platão, Benjamin, Kant, Nietzsche, Heidegger etc. São seus populosos fantasmas como os populosos personagens na mente de Balzac.

Essa prática indireta de literatura em alguns autores é diversa da tentativa direta de Barthes. Por isto, como bem diz Todorov, - "escândalo para uns, encantamento para outros, os textos de Barthes foram os de um escritor que as vicissitudes do destino teriam conduzido a fazer carreira no mundo das idéias e do conhecimento". Mas, onde se instala a "originalidade" de Barthes como "romancista", começa o risco do exercício da critica. E aqui, de novo, Todorov corajosamente alerta. Se a atitude de Barthes teve o efeito de refrescar, oxigenar a atmosfera de arrogância que caracteriza a comunidade intelectual, por outro lado, após "esse efeito profilático", está o risco da "renúncia ao discurso que tem a verdade como horizonte", com o risco de se cair no "relativismo generalizado". ${ }^{18}$

De resto, apesar de uma série de contribuições que Barthes trouxe ao estudo da semiologia, com razão, ainda, Todorov aponta que há outro aspecto discutível do conceito de crítica de Barthes, quando ele reduz a crítica a uma "tarefa puramente formal" e a "reconstituir as regras e contraintes na elaboração do sentido".

Barthes é um dos grandes semiólogos do século XX. Sendo um estudioso dos sinais, enquanto crítico utiliza-se da linguística como instrumento fornecedor de modelos interpretativos. Interessa-lhe a "letra" tanto na sua materialidade, quanto no seu sentido simbólico. É na articulação das letras dentro das palavras, na constituição do texto e do discurso que procurará o(s) sentido(s). No livro onde estão os textos sobre Cy Twombly, por sinal, alguns ensaios denotam já no título esta estratégia: "O espírito da letra", "Erté ou ao pé da Letra". E um dos exemplos mais claros sobre a letra como atomização do sentido está na análise que fez noutra ocasião da novela de Balzac Serrrazin, onde a tensão entre $S$ e o $Z$ resumem semioticamente a questão não apenas onomástica - o $\mathrm{S} / \mathrm{Z}$ dentro do nome de Serrazin, mas a identidade e o hermafroditismo do/da personagem.

Só um crítico tantalizado pela letra e pelo "grau zero da escritura" teria olhos para ver na obra de Cy o que Barthes viu. Barthes, neste sentido, pertence a essa geração de semiólogos que, a partir de Saussure (um dos criadores da semiologia), reinventaram os estudos nas ciências humanas e sociais. Nos anos 40, 50, 60 e 70 a linguística era chamada orgulhosamente de "o carro-chefe" das ciências humanas e sociais. Por isto, ela tomou a dianteira e conheceu, acadêmica e editorialmente, o seu apogeu. A entrada em cena

${ }^{17}$ HOTTOIS. História da filosofia: da renascença à pós-modernidade, p. 77.

${ }^{18}$ TODOROV. Critique de la critique. Un roman d'apprentissage, p. 79. 
de Jakobson e outros linguistas originários do Circulo de Praga e de Moscou; a antropologia de Levy-Strauss baseando-se abertamente nos estudos linguísticos para analisar a culinária ou as relações de parentesco; o surgimento de Lacan, baseando-se linguisticamente em suas análises do inconsciente instituído como linguagem; pensadores surgidos na esteira do estruturalismo, como Foucault e Derrida, que, se posicionando como sofistas, desenvolviam fascinantes jogos verbais na raiz de seus raciocínios; enfim, tudo isto foi vivido por minha geração, que atravessou o "corte epistemológico"(Bachelard, Marx, Saussure, Nietszche/Heidegger) reafirmando a paixão pelos signos linguísticos e gráficos.

Mas, passado algum tempo, é imprescindível um olhar crítico sobre o que antes fascinava e hoje pode ser visto mais objetivamente.

\section{De "VIRGIL" Às VISÕES DE HILDEGarda}

As hipervisões de Barthes valorizando a mais apagada inscrição de um ou outro nome entre as manchas sobre a tela de Cy Twombly se sucedem. Refere-se ele também ao quadro "Os italianos" (que vi pessoalmente no Beaubourg), quadro que segue o mesmo padrão de Cy de escrever/inscrever um grafiti mal feito e ao acaso sobre a massa de cores uniformes. Olha-se o quadro e tem-se a noção de equívoco e desperdício. Menos para Barthes, que diz: "A tela chama-se 'The Italians', no entanto, não se deve procurar por italianos a não ser no nome. Twombly sabe que o Nome tem o poder de evocação absoluto: escrever 'Os italianos' é ver todos os italianos”.

Observemos: diz ele que não deveremos procurar pelos "italianos" em outras partes do quadro, "a não ser no nome". Ou seja, não é o que está dentro, é o que está fora do quadro, na subjetividade, o que interessa. Mas há algo aí igualmente intrigante: será que essa afirmativa de que o "nome tem o poder de evocação absoluto" - fenômeno que ocorre sobretudo nos mitos e na religião, será que isto confere com a sensação de outros leitores e expectadores deste quadro? Uma tela clara, meio abstrata, com umas manchas, uma garatuja "preguiçosa", uma má caligrafia, como reconhece Barthes, será isto que vai desencadear esse milagre, essa epifania, esse "satoris" de lançar na nossa mente toda uma cultura romana, "todos" os italianos?

Noutra parte referi-me a algo a que chamo de "síndrome da marmota", uma vez que esse animal fica excitado quando vê qualquer coisa branca e isto o torna presa fácil dos caçadores. Mas aqui releva também mencionar uma experiência científica de percepção, quando nossos olhos veem numa superfície branca uma cor que não está nela e sim numa imagem anteriormente vista. É como se houvesse um transplante de imagem:

Quando você fixa por muito tempo o olhar sobre uma superfície de uma cor forte e depois muda rapidamente o olhar para uma superfície branca, você vê uma mancha colorida, mas de uma cor diferente da que você fixou antes. E depois de alguns instantes, verá novamente apenas a superfície branca. Esse fenômeno chamado de pós-imagem cromática nos leva à pergunta: essa cor que você vê está indo da superfície para o seu olho ou do seu olho para a superfície? Se ela não está na superfície branca, você está tendo uma alucinação? Está vendo algo que não existe? ${ }^{19}$

${ }^{19}$ VASCONCELLOS. Pensamento sistêmico: o novo paradigma da ciência, p. 136. 
Por isto, o cientista Huberto Maturana, numa clave que nos ajuda a entender o desvio de Barthes, admite a "emergência das cores na linguagem".

Causa admiração, estupefação e nenhuma inveja o fato de Barthes expor seu vezo erótico diante de Cy Twombly ao confessar que, diante do "gesto" e da caligrafia de Cy Twombly, o espectador pode "gozar". O crítico quer pespegar nos quadros a eroticidade que só existe em seus textos. E causa estranheza que, diante da escassez da obra, o crítico veja uma fartura de significados, como se estivesse diante de um clássico grego:

O que se passa na cena proposta por Twombly (tela ou papel) é algo que participa de vários tipos de acontecimento, que os gregos distinguiam muito bem em seu vocabulário: há o fato (pragma), um acaso (tuche), um fim (telos), uma surpresa (apodeston) e uma ação (drama). ${ }^{20}$

Inteligente e erudito, é verdade, mas uma derivação completamente alucinada em relação à obra estudada.

E como Barthes insiste em seu texto em fazer aproximações místicas, trazendo impropriamente o "zen japonês", o Tao, etc., pelo mesmo paradigma, mais acertado seria, criticamente, aplicar a ele e não a Cy Twombly o que se poderia chamar de a síndrome de Hildegarda.

O neurologista Oliver Sacks, estudando várias afetações e distúrbios da visão, lembra o que ficou conhecido como as "visões de Hildegarda" ${ }^{21}$ - um manuscrito de 1180, no qual a religiosa registrou uma série de visões sublimes e inefáveis que seriam clínica e cientificamente nada mais nada menos que o fenômeno conhecido como "fotismo": é um tipo de sensação ligada ao êxtase histérico ou psicótico, que pode ser produzido também por enxaqueca, intoxicação ou até manifestação epiléptica. Na opinião de alguns cientistas, as visões da santa provinham mesmo de enxaqueca. Há representação de estrelas, pontos de luz que se movem, figuras circulares concêntricas com certa agitação fosforescente.

O mais importante é que a santa dizia ter essas visões dentro de estados de absoluta normalidade. Não tinha sofrido nenhuma lesão cerebral, nem tomado nada em especial. Ela garante:

as visões que eu tive não as contemplei durante o sono, nem em sonhos, nem na loucura, nem com meus olhos carnais, nem com os ouvidos do corpo, nem em lugares ocultos, mas acordada, alerta e com os olhos do espírito e os ouvidos interiores; eu as percebo com a vista desimpedida e conforme a vontade de Deus.

No entanto, quando a santa descreve a chuva de estrelas cadentes que se transformam em carvão, o médico é levado a outra interpretação, que não a mística: "nossa interpretação rigorosa é que uma chuva de fosfenos atravessou seu campo visual, e a passagem foi sucedida por um escotoma negativo".

Que chuva de fosfenos verbal e cultural atravessa o campo visual-intelectual de certos críticos e teóricos, desencadeando estados de êxtase místico, provocando verdadeiros "satoris"?

${ }^{20}$ BARTHES. O óbvio e o obtuso, p. 161.

${ }^{21}$ SACKS. O homem que confundiu sua mulher com um chapéu. 
A sedução da escrita e o arrebatamento retórico podem ter a força de um alucinógeno. Sabemos disto todos os que escrevemos. Sabem-no mais abertamente os poetas e ficcionistas e até mesmo os ensaístas. Barthes possivelmente sabia dessa sua irrefreável transgressão, mas o que ele ganha em "prazer do texto" perde em rigor crítico. E já que estamos nos referindo ao quadro "Virgil" de Twombly e já que estamos tratando da questão da "percepção crítica" e da "interpretação", é esclarecedor recorrermos agora a dois textos do médico e neurologista Oliver Sacks, que ajudam a entender mais claramente alguns pontos hermenêuticos dessa abordagem.

Relata Sacks que teve um cliente de nome Virgil. A semelhança do nome desse personagem com a inscrição "Virgil" no quadro de Cy Twombly analisada por Barthes passa a ser uma sugestiva aproximação clínica e analítica. Enquanto Barthes "vê" no nome "Virgil" uma ressonância numerosa de significados, o Virgil de Sacks era uma pessoa que nasceu praticamente cega, mal percebia umas luzes e sombras. No entanto, submetido a operações, ele começou a ver.

O médico e cientista Oliver Sacks tornou-se conhecido pelo livro O homem que confundiu sua mulher com um chapéu. Ele narra a experiência vivida por um cliente, que sendo um bom cantor e músico, lá pelas tantas, começou a não reconhecer a fisionomia de pessoas e a não saber mais para que serviam certos objetos. Assim, era capaz de olhar uma luva e não saber o que era aquilo e em certos momentos até confundia seu próprio pé com um sapato.

Isto se prendia a certas anomalias do lado esquerdo de seu cérebro. Certo dia, saindo do consultório de seu médico, ocorreu a cena que deu nome ao famoso livro. O paciente "começou a olhar em volta à procura de seu chapéu. Estendeu a mão e agarrou a cabeça de sua mulher, tentou erguê-la e tirá-la para por em sua cabeça. Parecia que ele tinha confundido sua mulher com um chapéu! Ela olhava como se estivesse acostumada com coisas assim".

Dr. Sacks, entre as várias indagações diante do insólito do caso, ressalta: "Como é que ele podia, por um lado, confundir sua mulher com um chapéu e, por outro, como aparentemente ainda fazia, lecionar na faculdade de música?"

É uma observação instigante, mais do que simplesmente curiosa. Estava ele diante de um cliente sofisticado, erudito, com o qual falava também de literatura, um cantor famoso que, no entanto, tinha um distúrbio mental peculiar. Na observação clinica do Dr. Sacks há uma frase assás relevante. Seu cliente "era capaz de falar sobre as coisas, mas não as via face a face". Ou seja, as coisas não tinham "conteúdo", não tinham "função", apenas formas.

Em diversos momentos da arte moderna e contemporânea surgiram movimentos e artistas com uma visão apenas formalista da arte. É o caso de se indagar se a preferência não seria decorrente de certas formações cerebrais e não apenas de opções teóricas. É de se supor que a ciência teria algo a dizer a este respeito. E sem querer colocar isto exatamente no nível da patologia, torna-se ilustrativo lembrar com o dr. Sacks, que o seu cliente era sintomático de uma determinada visão das coisas. Pertencia ao grupo dos que só vêem formas, só se interessam pelo aspecto exterior.

No plano estético, o artista formalista elimina e ironiza conceitos como "conteúdo", "interior", "subjetivo". Seria extenso citar aqui uma série de afirmações teóricas redutoras, que, em oposição aos que dizem que a obra é o seu conteúdo, enfatizam que a forma é 
o verdadeiro conteúdo de uma obra de arte. E uma crítica como Rosalind Krauss e o psicólogo Rudolf Arheim têm instigantes estudos sobre isto.

É importante que o dr. Sacks, sem querer fazer teorias estéticas, esteja dando informações para uma revisão de questões que desorientam artistas e atormentam teóricos. Ele diz que não se pode ignorar, tanto na ciência, como na neurologia e na psicologia, a questão do "julgamento", ou seja, a "capacidade de discernir". E assinala que é "precisamente a derrocada da capacidade de discernir (...) que constitui a essência de numerosos distúrbios neuropsicológicos".

O que ele diz a respeito de certas esferas de conhecimento pode ser aplicado à questão da percepção artística. Sem discernimento, tanto o homem quanto o animal perecem. Por isto, o cientista vai dizer que não apenas "o discernimento é a faculdade mais importante que possuímos", mas, sobretudo, deve ser a "primeira" (e ele grifa essa palavra), "primeira faculdade da vida superior ou mente". Mas ele reconhece que esta faculdade tem sido "menosprezada".

Poder-se-ia pensar que o texto crítico, além de ser um óculos para ver melhor certos objetos/fatos, acabe tendo a função de operar, operacionalizar um milagre da visão. Isto pode ocorrer. Mas, no caso presente, em estudo, temos um óculos que é ele mesmo a tela.

Quando entramos em certas exposições ou estamos em determinadas situações, temos o ímpeto de dizer a um amigo - "você tem que ir lá para ver", como quem diz, "ver para crer", ${ }^{22}$ num duplo sentido. Esta solicitação para que o outro venha "ver para crer", pode ocorrer também diante de algo tão maravilhoso e arrebatador que não temos palavra para transmitir, só vendo para ver. Mas pode referir-se também a algo absurdo e inacreditável, algo que nos leve a indagar como foi possível que tivessem acreditado que aquilo merecia tal exposição e louvor?

Daí decorre outra situação, o "crer para ver": só os fiéis podem ter a visão, o arrebatamento. Só os que comungam da mesma fé (ou paradigma) verão o que aos outros, ignóbeis, não é lícito ver. Nesse sentido a bibliografia de Cy Twombly oferece outros exemplos de pessoas que passaram pelo "satoris" diante da insignificância que esboça. David Sylvester, nessa confraria, sente "enlevo" e, para ele, diante das obras de Cy Twombly, "a cena é etérea, inebriante, exasperante, sensual, supensa". ${ }^{23}$ Então, a questão da visão, num certo momento, pode deixar de ser algo pessoal, para ser um fenômeno grupal e social. Assumese a linguagem ou a visão do outro como forma de se ter linguagem ou visão. Enxergase com a linguagem e olho alheios. Quem não vê como determinado grupo vê é excluído. Quem não vê como o texto de um autor/autoridade está vendo é cego. Ver diferente, portanto, é correr o risco da exclusão. É disto que falam lendas e mitos pedagogicamente

Por que alguns vem demais, outros veem de menos? Por que não vemos? Por que não vemos o que não vemos? Sim, muitos veem, mas não sabem de onde se origina o seu modo de ver. E se o soubessem veriam o próprio modo de ver de maneira diferente. E se vissem seu modo de ver de maneira diferente, veriam a própria visão se vendo.

Irrompe aqui uma questão de dupla face: a linguagem como condutora da visão e como propiciadora da cegueira. A linguagem pode ensinar, aguçar, orientar a visão, mas

22 VASCONCELLOS. Pensamento sistêmico: o novo paradigma da ciência.

${ }^{23}$ SYLVESTER. Sobre arte moderna, p. 59. 
pode também aprisioná-la. E este o desafio do discurso crítico dialético. A linguagem pode operar/operacionalizar desvelamentos, que cheguem ao conhecimento ou à alucinação, e pode igualmente operar/operacionalizar ocultamentos.

A psicanálise, por exemplo, pretende ser um modo de pontuar linguisticamente o discurso do paciente para que ele se dê conta de si mesmo, para que se "veja". A filosofia muitas vezes instrumentaliza a linguagem e as etimologias como forma de desvelar o sujeito. A crítica sempre almejou algo parecido em relação ao texto. Houve um tempo em que se acusava certa crítica de ser "impressionista", nascia realmente de impressões e anotações subjetivas sem preocupação de constatação no interior da obra. Sobreveio depois uma crítica que procurou sondar e estabelecer as estruturas do texto/obra. Mas, em certos casos, como o que estamos assinalando, o devaneio tornou-se preponderante.

Como relatam neurologistas, os cegos ou os que têm distúrbios de visão não apenas se orientam pela linguagem, mas a fala, o discurso, quando pronunciado, faz com que o paciente fixe sua atenção e comece a ver. Há vários exemplos em que o indivíduo começa a ver o objeto depois que alguém o nomeia ou chama verbalmente sua atenção fazendo com que a audição (ou o discurso) ajude a visão. A palavra surge então como instigadora, como condutora do olhar, mostrando que o conceito pode ajudar a configurar a coisa pré-existente. A propósito, o dr. Sacks relata que Virgil, quando estava diante de um desafio de ver, "não fazia a menor idéia do que estava vendo. Havia luz, movimento e cor, tudo misturado, sem sentido, um borrão. E então, do meio da nódoa veio uma voz que dizia: 'Então?'. Foi neste instante, ele disse, que finalmente se deu conta de que aquele caos de luz e sombra era um rosto - e, na realidade, o rosto de seu cirurgião". ${ }^{24}$

A pergunta "e então?" desaba reincidentemente sobre o espectador diante de certas obras e quadros. E então? Mas, atenção! Entre orientar a visão para algo que realmente existe e impregná-la de fantasia, há uma diferença. Não significa que qualquer coisa que alguém diga verbalmente (salvo nos casos de hipnose) passe a ser visto e vivido pelo paciente. Se eu afirmar a um cego que a cadeira em que ele está assentado é um cavalo, ele saberá que estou mentindo ou tentando iludi-lo. Portanto, no espaço consensual da realidade, o próprio discurso tem suas limitações. Só Deus pode dizer: "Fiat" e as coisas começam a existir. Evidentemente, filósofos e retóricos podem ter surtos de demiurgos. Mas é em relação a isto que estamos nos acautelando.

Em síntese, estamos de acordo que se aprende a ver. De alguma maneira, entrando agora no campo literário explicitamente, eu diria que esse Virgil do dr. Sacks realiza um aprendizado muito semelhante ao do personagem Martin, no romance de Clarice Lispector A maçã no escuro, o qual, depois de um "crime" (ou ato radical), começa a redescobrir progressivamente a realidade. Redescobre o mundo mineral, vegetal, animal até o encontro com a mulher e o "outro", aprendendo, de novo, a nomear as coisas e a ter consciência de si enquanto sujeito. As experiências desse personagem podem ser estendidas até outros textos ficcionais de Clarice, pois Virgil do dr. Sacks também vai ao zoológico (como ocorre com outro personagem de Clarice diante do búfalo) fazer o aprendizado e apreensão do que seja o gorila, o emu, enfim, aquilo que há de desconhecido e animal em nós.

${ }^{24}$ SACKS. Um antropólogo em Marte, p. 118. 
Infelizmente, o destino do personagem real do Dr. Sacks é mais triste. Ele não resistiu ao ato de ver e de se ver no mundo, e, adoecendo, faleceu. Por isto, seu médico refere-se a estudos feitos por Marius von Senden e ao livro $O$ cego que se recusa a ver de 1771, no qual o paciente, sentindo-se ameaçado pela visão, ameaçou arrancar os próprios olhos. Édipo, como sabemos, foi mais radical: arrancou os olhos porque viu demais.

Este é um tema fabuloso e intrigante e tem a ver com questões epistemológicas, com questões de medicina, de crítica de arte ou literatura. Consideremos, contrastivamente, duas frases. Primeiro a de um paciente que disse a um médico: "É preciso morrer como uma pessoa que vê para poder renascer como cego". ${ }^{25}$ Essa é uma situação dentro da clínica. Mas eu diria que esta é a sugestão e palavra de ordem dentro da modernidade desde que Duchamp fez a apologia falaciosa do "homem cego".

Mas considere-se também, e finalmente, com o dr. Sacks, a desafiante recíproca verdadeira que deve superar os velhos paradigmas da modernidade: "é preciso morrer como um cego para renascer como uma pessoa que vê". ${ }^{26}$

\section{A}

\section{A BSTRACT}

This paper examines the limits of interpretation, based on Barthes's reading of three drawings by Cy Twombly.

\section{KEYWORDS}

Barthe. Twombly. Aesthetics. Interpretation.

\section{REFERÊNCIAS}

BARTHES, Roland. O óbvio e o obtuso. Rio de Janeiro: Nova Fronteira, 1990.

BARTHES, Roland. Erté. Rio de Janeiro: Nova Fronteira/FMR, 1976.

BOUDON, Raymond. Misère du relativisme. Commentaire, Paris, v. 29, n. 116, hiver 2006-2007.

CHADWICK, Whitney; COURTIVRON, Isabelle de (Ed.). Significant Others. New York: Thames \& Hudson, 1996.

DELROSCIO, Nicola. Writing on Cy Twombly. Schinner/Mosel, s/d.

HOTTOIS, Gilbert. História da filosofia: da renascença à pós-modernidade. Lisboa: Instituto Piaget, 2003.

LEEMAN, Richard. Cy Twombly. London: Thames \& Hudson, 2005.

SACKS, Oliver. O homem que confundiu sua mulher com um chapéu. São Paulo: Companhia da Letras, 2005.

SACKS, Oliver. Um antropólogo em Marte. São Paulo: Companhia das Letras, 2006.

SYLVESTER, David. Sobre arte moderna. São Paulo: Cosacnaif, 2007.

TODOROV, Tzvetan. Critique de la critique. Un roman d'apprentissage. Paris: Seuil, 1984.

VASCONCELLOS, Maria José Esteves de. Pensamento sistêmico: o novo paradigma da ciência. Campinas: Papirus; Belo Horizonte: Puc Minas, 2002.

\footnotetext{
${ }^{25}$ SACKS. Um antropólogo em Marte, p. 144.

${ }^{26}$ SACKS. Um antropólogo em Marte, p. 144.
} 